charm. He was very much a scholar of Russian literature, but his interests were not confined to his own field. As a senior professor he took courses and became quite an expert in mathematical statistics as well as Greek literature. He also loved the moun tains and climbed all fifty-four of Colorado's 14,000-foot peaks. He spent the all too few years of his retirement in the beautiful setting of Seeley Lake, Montana, where he died on 15 October 1995. He is survived by his sister, Anne, by his six children, Ian, Peter, Tina, Helen, Carl, and Eileen, and by six grandchildren.

\author{
Paul Drbreczeny \\ LAWRENCE: Frinberg: \\ University of North Carolina, Chapel Hill \\ Hugh MCLEAN \\ University of California, Berkeley \\ February 1996
}

\title{
Iakov Solomonovich Lur'e, 1921-1996
}

Iakov Solomonovich Lur'e, the distinguished Russian medievalist and cultural historian, passed away on 18 March 1996 in St. Petersburg following abdominal surgery. He was well known to many American colleagues as an outstanding member of the generation of scholars who emerged in the postwar years and who, during the subsequent thaw, struggled to revive the academic standards and interests of the distinguished pre-Stalinist schools of Russian historiography.

The son of the famous classicist Solomon Iakovlevich Lur'e (1891-1964), Lur'e was a precocious student, entering Leningrad State University at sixteen and obtaining his kandidat degree at twenty-one with a dissertation on Anglo-Russian relations in the sixteenth century. In these early years his most important teacher was the historian Mikhail Dmitrievich Priselkov (1881-1941), whom he admired throughout his life. (The preparation of a collection of Priselkov's works was one of Lur'e's last undertakings.) After wartime evacuation in Eniseisk, Vologda, and Arkhangel'sk, where he began to teach, he returned to Leningrad and became a popular instructor in the Herzen Pedagogical Institute. In 1949, however, he was labeled a "rootless cosmopolitan," removed from his job, and denied formal employment for four years. Although he eventually found a home as a research fellow, first in the Museum of the History of Religion (Kazanskii Sobor, 1953-56) and later in the Pushkinskii dom of the Soviet Academy in Leningrad (1956-82), he was never again allowed to teach.

His research continued unabated, however, even after he was forced out of the Pushkinskii dom by police pressure for having defended a young colleague against repression by the KGB. In fact, his last years were in many ways his most productive. Freed from the small and middling idiocies of the Soviet institut, he completed not only what may well be seen in retrospect as his most valuable historical monograph (Dve istorii Rusi XV veka, 1994), but also some works of interpretation, long in gestation, on his favorite prerevolutionary and Soviet authors (Posle L'va Tolstogo, 1993; V kraiu nepugannykh idiotov: Kniga ob Il'fe $i$ Petrove, 1983), and a reminiscence of his father (Istoriia odnoi zhizni, 1987). Lur'e particularly relished the publication of the latter two titles, which appeared under the pseudonyms Avel' Adamovich Kurdiumov and Bogdana Ikovlevna Koprzhiva-Lur'e, respectively.

Among American students of Muscovy, however, Lur'e will probably be best remembered for his important studies of Muscovite chronicles and ecclesiastical politics 
and for his scrupulous and comprehensive editions of the works of Afanasii Nikitin and Iosif Volotskii and of the Kurbskii-Groznyi correspondence. Leaving an appreciation of these major contributions to a more appropriate occasion, here one can only note Iakov Solomonovich's great productivity, the more astonishing for having been achieved under conditions that were often very adverse, not only as a conse. quence of wartime conditions or anti-Semitic campaigns, but no doubt in part because of his utter fearlessness in the face of official academic derzhimordstwo.

Two particularly vivid episodes come to mind. The first took place in 1962-63, during one of the more disgraceful episodes in the history of Soviet "scholarship": the collective pillorying of Aleksandr Zimin for having suggested that the Igor Tale was a late eighteenth-century pastiche, composed by a Ruthenian monk, Ioil' Bykovskii. As is now clear from partially published correspondence, Lur'e, who did not himself accept Zimin's conclusions, was almost alone in refusing to participate in the closed "discussion" that was led and orchestrated by Dmitrii S. Likhachev. Lur'e's courage is the more remarkable for the fact that Likhachev was his quondam patron, nominal boss, and arguably the most powerful humanist in the Academy.

Lur'e's expulsion from the Pushkinskij dom was the direct result of his willingness to stand as character witness for his assistant Arsenii Roginskii, who had been arrested after it was discovered that he was the editor and publisher of the fine tamizdat doc. umentary albums Pamiat' (5 vols., 1978-82). Certainly these and other acts of civic courage and intellectual autonomy explain a seeming paradox: while universally acknowledged as Russia's leading medievalist, Lur'e was never awarded any of the honorary titles and prizes made so much of in the Soviet Academy and showered upon charlatans and complaisant nonentities.

Widely known for his sharp tongue and warmly admired for his integrity, Iakov Solomonovich was, as the present writer can attest, a ferocious debater, a formidable but always punctiliously just adversary. His death is a particularly grievous loss for the community of Russian medievalists in these generally calamitous times. He is survived by his wife, Irina E. Ganelina, a son, Lev, and two grandchildren, all of St. Petersburg.

EDWARD L. KrHNAN Harvard University May 1996

\section{Viktor G. Bortnevskii, 1954-1996}

Viktor Bortnevskii's research specialty was the White Army and administration during the Russian Civil War (1918-21). In both his scholarly and his public life, he worked tirelessly to paint an accurate picture of Russia's lost anti-Bolshevik alternatives and to bring to the current generation a feeling for the Russian cultural and social world that was interrupted by 1917 .

His active career spanned the Soviet, perestroika, and post-Soviet periods of recent Russian history. Even before it was fashionable in Russia to do so, his work represented an attempt to deal fairly and objectively with the White movement in the Russian Civil War. Never one to hide his views, his forthright statements and writings on both Russian history and public policy earned him powerful enemies and a place on the secret list of those to be arrested in Petersburg, had the 1991 coup succeeded.

Equally important was his pioneering interview work with surviving veterans of the White Army in the west. He sought out these veterans wherever they could be 